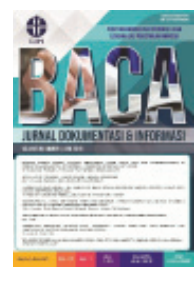

\title{
TRANSFER PENGETAHUAN MELALUI MEDIA SOSIAL OLEH STAF AHLI ANGGOTA LEMBAGA NEGARA MAHARDHIKA
}

\author{
Melly Kartika Adelia ${ }^{1^{*}}$, Laksmi \\ ${ }^{1}$ Pasca-Sarjana Ilnu Perpustakaan, Fakultas Ilmu Budaya, Universitas Indonesia \\ ${ }^{2}$ Departemen Ilmu Perpustakaan dan Informasi, Fakultas Ilmu Budaya, Universitas Indonesia \\ *Korespondesi: mellykartikaa@gmail.com
}

Diajukan: 03-11-2017; Direview: 11-04-2018; Diterima: 17-05-2018; Direvisi: 19-05-2018

\begin{abstract}
This research seeks to understand the process of action of expert staff of Legislative Assembly of Mahardhika in fulfilling its duties and functions namely decision making by considering public opinion, as well as a means of building the image of member of state in expressing itself personally and institution. This research uses case study method with qualitative approach. Informants were determined based on purposive sampling method and obtained five people. The results of this study indicate that in the knowledge transfer through social media in the Legislative Assembly of Mahardhika done based on the understanding of the team of expert staff that social media is associated with the concept of the corporation or organization which is interpreted as a medium that has the purpose to provide information to the public in accordance with the existing moment, while the purpose of using social media by expert staff is more aimed at reaches the wider community. The application of knowledge transfer by expert staff through social media is done in five steps, namely intermediation, externalization, internalization, cognitive, and evaluation. The intermediation step, ie matching efforts between the communication agenda and the existing subject trend, is the most important and sustainable step. Social media that is the most effective in disseminating information to the public is Facebook, followed by Twitter and Instagram.
\end{abstract}

\begin{abstract}
ABSTRAK
Penelitian ini berusaha memahami proses tindakan staf ahli Lembaga Negara Mahardhika dalam memenuhi tugas dan fungsinya, yakni pengambilan keputusan dengan mempertimbangkan opini publik, sekaligus sebagai sarana membangun citra anggota Lembaga Negara dalam mengekspresikan dirinya secara personal dan institusi. Penelitian dilakukan menggunakan metode studi kasus dengan pendekatan kualitatif. Informan ditentukan berdasarkan metode purposive sampling dan diperoleh lima orang. Hasil penelitian menunjukkan bahwa dalam transfer pengetahuan melalui media sosial di Lembaga Negara Mahardhika dilakukan berdasarkan pemahaman tim staf ahli, media sosial dikaitkan dengan konsep korporasi atau organisasi dimaknai sebagai media yang memiliki tujuan untuk menyediakan informasi kepada publik sesuai dengan waktu yang ada. Sedangkan tujuan penggunaan media sosial oleh staf ahli lebih ditujukan untuk menjangkau masyarakat lebih luas. Penerapan transfer pengetahuan oleh staf ahli melalui media sosial dilakukan dalam lima langkah, yaitu intermediasi, eksternalisasi, internalisasi, kognitif, dan evaluasi. Langkah intermediasi, yaitu upaya pencocokan antara agenda komunikasi dengan tren subjek yang ada merupakan langkah yang paling berperan dan berkesinambungan. Media sosial yang paling efektif dalam penyebaran informasi kepada masyarakat adalah Facebook, kemudian Twitter dan Instagram.
\end{abstract}

Keywords: Knowledge transfer; Legislative Assembly; Expert staff; Social media

\section{PENDAHULUAN}

Transfer pengetahuan merupakan suatu hal penting bagi perkembangan dan keefektifan organisasi. Transfer pengetahuan merupakan salah satu bagian dalam manajemen pengetahuan yang merupakan sebuah ilmu yang mempromosikan pendekatan terintegrasi untuk mengidentifikasikan, mengkategorikan, mengambil kembali, dan berbagi aset informasi suatu 
organisasi (Yates, 2011). Saat ini manajemen pengetahuan mulai meninggalkan cara konvensional dan kemudian beralih ke manajemen pengetahuan berbasis teknologi.

Pesatnya perkembangan teknologi informasi dalam beberapa tahun terakhir telah menjadikan internet sebagai alat komunikasi yang banyak digunakan masyarakat. Terjadinya perubahan komunikasi konvensional menjadi modern dan serba digital berdampak pada halhal yang serba instan, mudah, dan cepat dalam mangakses informasi di situs online dan media sosial. Melihat fenomena penggunaan media sosial, Anggota Lembaga Negara Mahardhika (selanjutnya disebut Anggota LNM) menggunakan media sosial untuk pengambilan keputusan dan kegiatan yang dilakukan dengan mempertimbangkan opini publik terkait suatu isu dan sebagai sarana untuk membangun citra (Nirmala \& Vemuri, 2009).

Keberadaan pengetahuan yang bersumber dari media sosial ini dimanfaatkan oleh Anggota LNM untuk menugaskan staf ahli untuk mengendalikan, memonitor, mengolah, dan menyebarkan pengetahuan melalui akun media sosial. Manajemen pengetahuan sangat penting dilakukan untuk membentuk opini publik melalui media sosial. Kesuksesan komunikasi melalui media sosial memiliki peranan yang penting bagi organisasi (Chua, 2013). Di Indonesia penelitian tentang manajemen pengetahuan sudah banyak dilakukan namun sebagian besar masih seputar manajemen pengetahuan konvensional sedangkan penelitian yang berbasis teknologi informasi masih terbatas. Melalui penelitian ini, peneliti tertarik ingin mengetahui proses transfer pengetahuan melalui media sosial khusnya dalam hal menyuarakan aspirasi melalui media sosial.

\section{TINJAUAN PUSTAKA}

\subsection{Penerapan Transfer Pengetahuan}

Transfer pengetahuan merupakan salah satu bagian dari manajemen pengetahuan, yang diartikan sebagai suatu kegiatan bertukar gagasan, hasil penelitian, pengalaman, dan keterampilan di antara individu di dalam suatu organisasi, bisnis, sektor publik, atau komunitas yang lebih luas, untuk memungkinkan pengembangan produk dan kebijakan baru yang inovatif (Dhiman \& Sharma, 2009; Bhatt, 2000). Transfer pengetahuan merupakan proses mengkonstruksi, mengekspresikan, memahami, atau menginterpretasi pengetahuan. Hal ini juga berlaku untuk artefak, yang diartikan sebagai hasil dari konstruksi para agen, melalui media, seperti media sosial, dan laporan yang digunakan dalam segala tindakan dan interaksi. Sementara itu, transformasi merupakan dinamika perilaku agen di dalam suatu konteks, dan para agen memiliki keunikan masing-masing, termasuk sistem nilai, norma, dan keyakinan. Hubungan sosial tersebut dapat mempengaruhi proses transfer pengetahuan secara keseluruhan, seperti adanya rasa saling menghargai, percaya, dan membantu termasuk kemampuan agen untuk menyerap pengetahuan baru, pengalaman, jabatan, dan status (Dhiman \& Sharma, 2009).

Menurut Frappaolo \& Toms (1999), dalam suatu organisasi ada lima tahapan dalam proses transfer pengetahuan, yakni sebagai berikut.

1) Intermediasi, merupakan proses transfer pengetahuan antara penyedia dengan pencari pengetahuan, dengan mencocokkan kebutuhan mereka dengan sumber pengetahuan. Intermediasi menjamin transfer pengetahuan berjalan lebih efisien. Contohnya adalah tim sukses salah satu calon dalam Pilkada yang menyebarkan informasi tentang latar belakang calon tersebut.

2) Eksternalisasi, merupakan transfer pengetahuan dari pikiran pemiliknya ke tempat penyimpanan eksternal secara efisien. Contohnya, tim sukses menuliskan dan 
menyebarkan opini calon Pilkada ke media masa dengan tujuan menarik simpati masyarakat.

3) Internalisasi, merupakan pengambilan pengetahuan dari tempat penyimpanan eksternal dan penyaringan pengetahuan untuk pengguna yang relevan. Pengetahuan harus disajikan dalam bentuk yang sesuai dengan pemahaman pengguna-dengan menginterpretasi format ulang penyajiannya. Contohnya adalah tim sukses yang menganalisis materi tertulis yang disusun oleh calon Pilkada dan mengolahnya kembali ke dalam bentuk baru yang dipahami masyarakat.

4) Kognitif, merupakan fungsi suatu sistem untuk membuat keputusan yang berdasarkan atas ketersediaan pengetahuan. Kognitif merupakan penerapan pengetahuan yang telah berubah melalui tiga fungsi terdahulu. Contohnya adalah tim sukses yang menganalisis dan menginterpretasi tanggapan masyarakat atas informasi yang disebarkan.

5) Evaluasi, merupakan kegiatan manajemen pengetahuan untuk mengukur, memetakan, dan mengkuantifikasi pengetahuan korporat dan kinerja untuk menciptakan solusi dalam manajemen pengetahuan. Contohnya adalah tim sukses yang mempelajari kembali, menganalisis, dan memahami seluruh kegiatan pengelolaan pengetahuan yang telah dilakukan.

\subsection{Jenis Pengetahuan}

Pengetahuan dibagi menjadi dua jenis, yaitu pengetahuan tacit dan explicit (Dalkir, 2011; Hislop, 2009). Pengetahuan tacit atau implisit adalah pengetahuan tak berstruktur, yang berada di dalam pikiran manusia. Pengetahuan implisit berupa wawasan, gerak hati, firasat, idealisme, nilai, dan emosi yang sulit dibagi kepada orang lain dan bersifat subjektif. Pengetahuan implisit memiliki dimensi teknis dan kognitif. Dimensi teknis menunjukkan pengetahuan implisit yang lebih bersifat informal dan know-how dalam melakukan sesuatu, relatif sulit didefinisikan dan dijelaskan. Dimensi kognitif, yang terdiri dari kepercayaan, persepsi, idealisme, nilai, emosi dan mental, menentukan cara seseorang menerima sesuatu. Pengetahuan eksplisit yaitu pengetahuan yang siap diakses, telah terdokumentasikan dalam sumber pengetahuan formal yang disusun secara runtun, dalam bentuk data, formula, spesifikasi produk, manual, dan tertuang dalam media tercetak seperti buku, koran, jurnal, laporan, majalah, dan media elektronik seperti internet, ebook, online journal, dsb. (Nonaka \& Takeuchi, 2003). Pengetahuan eksplisit lebih mudah ditemukan kembali dan ditransfer kepada orang lain jika dibandingkan pengetahuan implisit (Hislop, 2009). Gambar 1 menunjukkan pertukaran pengetahuan dalam suatu organisasi. 


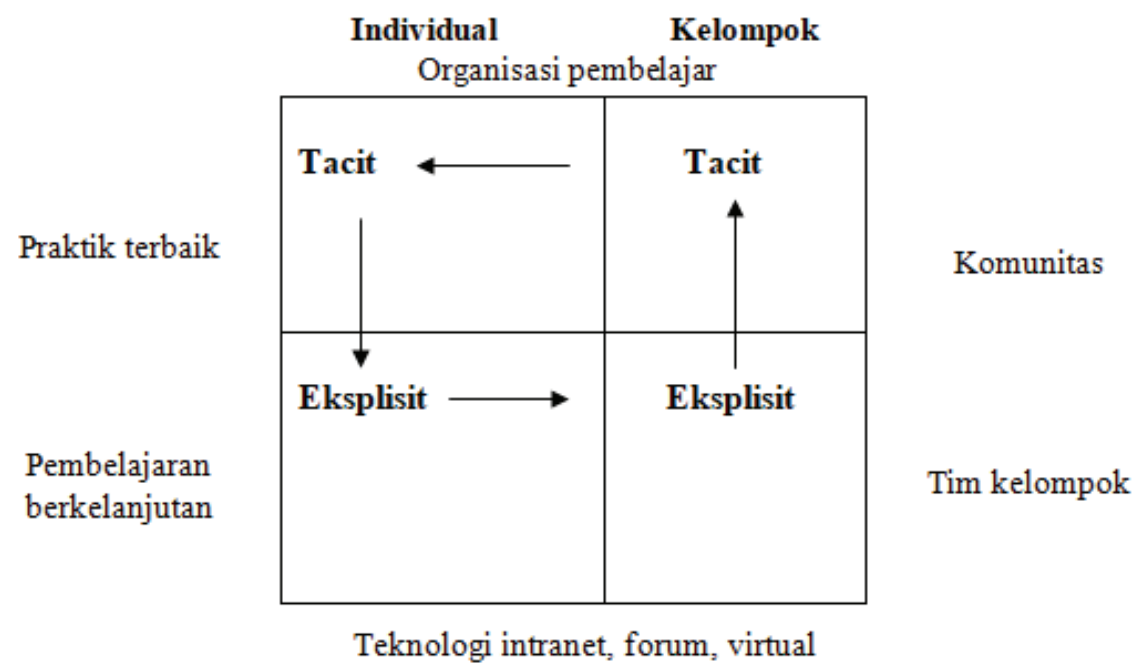

Gambar 1. Pertukaran pengetahuan dalam organisasi Sumber: Nonaka \&Toyama (2003)

Kedua jenis pengetahuan ini tidak dapat dipisahkan dari pengetahuan individual dan pengetahuan organisasi bahkan seluruh unsur saling berinteraksi satu sama lain (Blasius \& Imadianti, 2012). Pertukaran pengetahua dari tacit ke explicit memungkinkan organisasi untuk tumbuh berkembang sebagai organisasi pembelajar.

\subsection{Media sosial}

Media sosial adalah media online yang mendukung interaksi sosial, dengan menggunakan teknologi berbasis web untuk mengubah komunikasi menjadi dialog interaktif. Definisi lainnya adalah sebuah media di mana pengguna dengan mudah berpartisipasi, berbagi, dan menciptakan pesan. Beberapa situs media sosial yang populer sekarang ini antara lain Blog, Twitter, Facebook dan Wikipedia (Yates \& Paquette, 2011; Mulatiningsih \& Johnson, 2014). Media sosial memiliki tiga fungsi, yaitu: (1) media yang didisain untuk memperluas interaksi sosial manusia menggunakan internet dan teknologi web; (2) media sosial berhasil mentransformasi praktik komunikasi searah media siaran dari satu institusi media ke audiens (one to many) menjadi praktik komunikasi dialogis antar-audiens (many to many); (3) media sosial mendukung demokratisasi pengetahuan.

Media sosial memiliki karakteristik: (a) partisipasi, mendorong kontribusi dan umpan balik dari setiap orang hingga mengaburkan batas antara media dan audien (contohnya, media massa/ media siaran); (b) keterbukaan, kebanyakan media sosial terbuka bagi umpan balik dan partisipasi melalui sarana voting, komentar, dan berbagi informasi; (c) perbincangan, media sosial memungkinkan terjadinya komunikasi dua arah, lebih responsif dibanding dengan media yang lain; (d) komunitas, media sosial memungkinkan terbentuknya komunitas secara instan dan berkomunikasi secara efektif tentang beragam isu; (e) keterhubungan, mayoritas media sosial tumbuh subur lantaran kemampuan melayani keterhubungan antar-pengguna, melalui fasilitas tautan (link) ke situs, sumber informasi, dan pengguna lain (Mulatiningsih \& Johnson, 2014).

Penyebaran informasi menurut konteks penelitian ini, terdapat tiga media sosial yang dievaluasi, yaitu Twitter, Facebook, dan Instagram. 
- Twitter, media sosial hasil karya Dorsey. Besarnya minat masyarakat Indonesia terhadap media sosial Twitter dapat menjadi salah satu alasan mengapa banyak pula kalangan yang menggunakan media sosial ini. Twitter merupakan sarana untuk berkomunikasi dan berbagi informasi, ajang promosi, pencitraan pemberitaan, dan bisnis. Media sosial ini adalah situs tidak berbayar, berisi pesan yang hanya terdiri dari 140 karakter yang disebut tweet, dan disebarkan dengan sangat cepat kepada semua pengguna. Mereka dapat langsung melakukan pembicaraan dan berinteraksi dengan pengguna lainnya, dengan memakai simbol@ atau retweet, yaitu ketika pesan dari seorang pengguna diteruskan oleh pengguna kedua sebagai pengikutnya (follower), dengan memakai kode "RT @username" di awal pesan, sebagai kredit yang menunjukkan pembuat pesan terdahulu.

- Facebook, merupakan situs jejaring sosial sejak 2004, karya Mark Zuckerberg. Pengguna yang ingin menjalin pertemanan, cukup meng-klik fasilitas menambah teman dan melakukan verifikasi. Fitur yang disediakan mencakup fitur share link/photo/video untuk memudahkan dalam berbagi informasi; kolom komentar merupakan tempat yang disediakan ketika orang lain ingin merespon informasi yang dibagikan; menyediakan ratusan emotikon dengan berbagai karakter. Sebagai contoh, ekspresi senang diwakilkan oleh emotikon $\mathcal{*}_{\text {atau }} \cdot$, ekspresi bahagia memiliki emotikon $\dot{\mathcal{V}}$ atau $\dot{\mathcal{*}}$, dsb.

- Instagram, merupakan media sosial di dunia maya yang cukup populer, pengguna mengunggah foto di akun Instagram. Jika menarik dan bagus, banyak follower yang mem-follow akun tersebut. Media sosial ini adalah cikal bakal fitur hashtag (atau tagar dalam bahasa Indonesia, dikenal dengan lambang "\#”) untuk membantu pengguna menemukan foto yang bertopik serupa. Fitur hashtag ini kemudian dikenal dengan istilah "tag".

\subsection{Transfer Pengetahuan Masyarakat}

Dalam menjalankan kegiatan sehari-hari, staf ahli anggota lembaga negara memiliki tugas sebagai humas dalam menjalankan salah satu fungsi manajemen, yakni mengelola aspirasi atau pendapat yang terkait dengan citra pimpinan atau instansinya sendiri. Aspirasi yang datang dari masyarakat berbagai macam, bisa saran, kritik, pujian, bahkan opini/isu seputar instansi pemeritahan itu sendiri. Menurut Millet dalam Ruslan (2004), peran humas pemerintahan dalam menjalankan tugas dan kewajiban utamanya adalah: (1) mengamati dan mempelajari keinginan dan aspirasi yang terdapat dalam masyarakat; (2) memberikan nasihat atau sumbang saran dalam menanggapi yang sebaiknya dilakukan instansi/lembaga pemerintah, seperti yang dikehendaki oleh publik; (3) mengusahakan terciptanya hubungan memuaskan antara publik dengan para pejabat pemerintahan; memberikan penjelasan dan informasi tentang upaya suatu lembaga/instansi pemerintahan yang bersangkutan. Dapat disimpulkan bahwa pembentukan serta pengelolaan opini yang selama ini dilakukan oleh staf ahli anggota Lembaga Negara memiliki peranan yang penting.

\section{METODE}

Penelitian ini menggunakan pendekatan kualitatif, yang bertujuan untuk memahami suatu fenomena secara komprehensif. Fenomena mengenai manajemen pengetahuan yang terjadi dalam proses pembentukan opini publik melalui media sosial— proses natural yang dibangun oleh interaksi sosial yang membutuhkan pemahaman. Pengumpulan data melalui observasi, 
wawancara, dan analisis dokumen. Metode analisis yang digunakan adalah studi kasus, yaitu metode untuk menganalisis peristiwa atau gejala yang sedang berlangsung dalam ruang dan waktu tertentu, dalam konteks kehidupan nyata sehingga memperoleh gambaran yang utuh dan mendalam tentang penerapan transfer pengetahuan yang terjadi dalam pembentukan opini publik melalui media sosial (Connaway \& Powell, 2010). Penentuan informan menggunakan metode purposive sampling. Informan penelitiannya yaitu staf yang mempunyai wewenang menjalankan account media sosial Anggota LNM. Informan penelitian berjumlah 5 orang, yang terdiri dari 3 orang staf ahli, yaitu Ali, Jeni, dan Jono; 1 orang keluarga dari pemilik akun bernama Siska; dan 1 orang pemilik akun itu sendiri. Seluruh nama informan disamarkan.

\title{
4. HASIL DAN PEMBAHASAN
}

\subsection{Makna Media Sosial Menurut Staf Ahli}

Media sosial memiliki pengertian yang bermacam-macam tergantung konteksnya. Ada yang mendefiniskan media sosial sebagai media online yang mendukung interaksi sosial, ada juga yang memaknainya sebagai media untuk berpartisipasi, berbagi, dan menciptakan pesan, termasuk blog, jejaring sosial, wiki/ensiklopedia online, forum maya, termasuk virtual worlds. Media sosial juga dimaknai berbeda oleh informan Ali yang bekerja sebagai staf ahli, menurutnya media sosial merupakan informasi yang dikelola oleh publik yang bersifat natural karena tidak ada agenda untuk setting-an. Lebih lanjut Ali mengatakan:

\begin{abstract}
"media sosial sebagai sarana untuk bertukar informasi yang dikelola oleh publik. Media ini tidak memiliki hirarki pemberitaan dan settingan agenda yang baku, menyesuaikan dengan nilai popularitas sebuah berita, 20 Desember 2016".
\end{abstract}

Definisi media sosial menurut Ali tidak terlepas dari pekerjaannya yang merupakan staf ahli pengelola informasi publik. Berbeda dengan Jeni, ia memaknai media sosial sebagai tujuan yang berbeda, yakni untuk hal-hal yang bersifat privat dan korporasi. Untuk tujuan pribadi, lebih sebagai curahan hati, sedangkan tujuan korporasi sebagai sarana membagi agenda kegiatan. Berdasarkan pendapat dua informan di atas, ada persamaan dalam memberikan pengertian media sosial, yakni mengkaitkannya dengan konsep korporasi atau organisasi yang memiliki tujuan penyedian informasi untuk umum berdasarkan momen yang ada.

Kegiatan Media sosial di LNM lebih banyak bersifat publik, yakni memberikan informasi kepada masyarakat dengan memberikan informasi tentang pemilik akun. Tujuan dari penggunaan media sosial memiliki banyak keuntungan. Sebagaimana dikatakan Jono:

"mayarakat kita seperti apa dalam penggunaan facebook, ig (jenis- jenis media sosial), mereka selalu uptodate terhadap aplikasi kayak gitu, sehingga wajar juga kalo kita juga sebagai lembaga pemerintah nyebarin info lewat itu juga, lebih memasyarakat gitu mba..., 28 Desember 2016".

Berdarkan penjelasan ketiga informan dapat dikatakan bahwa tujuan penggunaan media sosial di organisasi untuk menjangkau masyarakat - tidak adanya intervensi dari pihak manapun. Menurut pemilik akun, dengan memiliki akun media sosial akan banyak sekali manfaat yang diperoleh, yakni untuk menjawab aduan, meluruskan informasi, ataupun memberikan motivasi ketika pemohon informasi mengalami masalah.

Pemilihan media sosial di LNM tidak serta merta tanpa alasan tetapi dalam penyebaran informasinya harus diperhatikan agar sesuai dengan karakteristik pembaca. Informan Ali mengatakan bahwa: 
"Untuk penyebaran informasi di LNM tergantung kebutuhan pemberitaan mbak, pembentukan opini yang bobot pemberitaannya ringan, WA dan BBM lebih efektif; sedangkan yang bobotnya lebih berat, twitter dan kompasiana melalui share FB lebih efektif, 20 Desember 2016".

Hal tersebut menurut (Malloney, 1985) sudah sesuai dalam teori agenda setting, bahwa diperlukan 3 stream agar sebuah opini menjadi konsumsi pemegang kepentingan (stakeholder); media yang biasa dirujuk pemerintah (government stream); dan media yang lazim dirujuk masyarakat kebanyakan (public stream) dan momentum. Faktor terpenting untuk mencapai ketiga hal tersebut adalah frekuensi kemunculan berita, semakin sering muncul, semakin cepat menjadi opini publik. Opini juga perlu disuguhkan dalam beragam bentuk agar menjadi konsumsi publik (meme, broadcast, opini pakar, dsb.).

\subsection{Proses Transfer Pengetahuan Sebagai Landasan kerja}

Proses transfer informasi yang ada di LNM dilakukan secara kolektif dengan tim yang telah dibentuk sesuai dengan tanggung jawab pekerjaannya. Aktivitas di LNM sangat dinamis, untuk itu kegiatan media sosial juga dilakukan secara fleksibel. Apabila staf ahli sedang tugas ke lapangan atau luar kota, maka staf ahli lainnya harus mampu menggantikan tugasnya untuk sementara. Selain itu, adanya keadaan perpolitikan di Indonesia yang sedang beredar di masyarakat, khususnya terkait kebijakan, yang secara mendadak harus diubah atau direvisi oleh Pemerintah. Dalam hal ini, staf ahli melakukan pekerjaan lebih berat dibanding hari biasanya karena harus memberikan respon informasi yang akan dikeluarkan selanjutnya.

Ada lima tahapan dalam proses transfer pengetahuan yang dilakukan oleh staf ahli LNM untuk mengelola dan menyebarkan informasi melalui media sosial ke masyarakat, yaitu intermediasi, eksternalisasi, internalisasi, kognitif, dan evaluasi.

\subsubsection{Intermediasi}

Tahapan intermediasi merupakan tahapan awal dari manajemen pengetahuan melalui media sosial. Intermediasi adalah upaya untuk mencocokkan informasi antara sumber informasi dengan pencari informasi. Dalam divisi sosial media, pengumpulan informasi lebih kepada upaya pencocokan antara agenda komunikasi dengan tren subjek yang ada sehingga agenda komunikasi dapat berjalan berdampingan dengan tren yang bersangkutan.

Penentuan tren yang dilakukan staf ahli pada akun milik Anggota LNM tidak bersifat subjektif ataupun tanpa adanya alasan yang melatarbelakanginya. Selama ini yang dilakukan oleh tim staf ahli media sosial sudah sesuai momentum yang tepat, baik yang bersifat pribadi maupun kelembagaan pemilik akun. Sebagai contoh, ada pemilik akun yang secara tiba-tiba menginformasikan ada pihak yang ingin mengganti jabatannya sebagai Pimpinan LNM. Hal tersebut direspon masyarakat dan walhasil masyarakat terkejut terhadap keputusan yang diambil. Di akun media sosial pun ramai, pro dan kontra dari masyarakat. Masyarakat sangat menyayangkan dengan adanya pihak yang ingin menjatuhkan karena selama ini pemilik akun dikenal sebagai pribadi yang santun dan tidak memiliki track recod yang buruk selama memimpin. Merespon hal tersebut, tim staf ahli harus bekerja lebih keras dan berhati-hati dalam memberikan berbagai informasi yang terkait dengan pemilik akun media sosial karena sedang menjadi perhatian masyarakat Indonesia. Namun, ketika ada momen yang bersifat pribadi, staf ahli juga menyebarkan informasi yang bersifat pribadi seperti mem-posting foto pemilik akun sedang memanjatkan doa di tanah suci di media sosial. Sebagaimana dikatakan Ali: 
"Tergantung momentum sih, bisa juga mengusulkan agenda baru mengikuti agenda kegiatan si pemilik akun, atau mengelola kabar dari orang terdekat pemilik akun, 20 Desember 2016".

Menurut Ali informasi di atas berorientasi aspek orang, fokus pada hasil intelektual yang merepresentasikan informasi pribadi pemilik akun. Siska yang notabene seorang anak dari pemilik akun, memberikan jawaban yang padat dan ringkas bahwa dirinya lebih menyukai informasi yang berhubungan dengan keluarga, seperti informasi umroh atau ulang tahun. Berikut ini perkataan Siska:

"Kalo saya pribadi sih kak, saya suka informasi yang ada di akun papa tentang acara keluarga, bukan berarti saya tidak suka yang berhubungan dengan informasi kedinasan yang papa share selama ini di akunnya. Soalnya kan disitu kita jadi bisa kumpul bareng dengan yang lainnya Kak, Kakak juga tahu kan ya kalo jadwal itu padat, jadi selagi ada acara keluarga pasti deh happening banget buat saya pribadi... hehehhe. Makanya saya suka kan WA ke staf Ahli, ayo kak share dong ke akun Papa..., 12 Januari 2017”.

Dengan pengetahuan akun tersebut, informan mendapatkan sebuah tren yang nantinya akan disetarakan dengan aspek kebutuhan informasi dalam ruang kajian siklus informasi sosial media. Hal tersebut dikatakan Jono:

"Menyesuaikan momentum atau mengusulkan agenda baru. Kalau kita biasanya lihat tren dulu mba,kayak adword dan sejenislah mba..., 28 Desember 2016".

Menurut Debowski (2006), teknologi merupakan peran pendukung yang penting dalam transfer pengetahuan - dibutuhkan pengguna yang kompeten dan percaya diri ketika menggunakan. Informan kedua cenderung mengkombinasikan aspek manusia dan aspek teknologi. Dalam pandangan Jono, penggunaan adword merupakan salah satu indikasi dari kombinasi dari aspek manusia dan aspek teknologi.

Proses merupakan pengaturan dan alignment dari strategi, prinsip, proses, praktik untuk memastikan bahwa manajemen pengetahuan dapat berjalan baik ketika diimplementasikan (Debowski, 2006). Aspek proses ini mencakup juga proses mediasi informasi dari informan ke individu, sebagaimana dikatakan Jono:

\footnotetext{
"Ya gitu, kadang kita juga melihat perkembangan tren di media. Kadang kita juga turun iseng di acara acara untuk memastikan tren tersebut. Walau malesnya minta ampun, tapi ya jalan juga ke acara tersebut, hitung-hitung bos lagi baik ngasih jajan buat ngopi. Namanya juga kerja non eksak mbak, pinter pinter nyari celah..., 28 Desember 2016".
}

Penerapan intermediasi dalam tim sosial media berorientasi terhadap media transfer informasi dari informan yang secara tidak langsung sebagai pencetus tren yang diasumsikan sebagai kebutuhan informasi publik-posisi lembaga yang mempunyai kesempatan untuk mempengaruhi kehidupan orang banyak. Di LNM, semua anggota tim memiliki peran yang jelas, misalnya Ali bertanggung jawab untuk mengendalikan media sosial Facebook, Jeni memiliki wewenang mengelola Instagram; dan Jono mengelola Twitter (Yates \& Paquette, 2011). Ketiga informan tersebut memiliki pengetahuan yang cukup dalam mengendalikan informasi melalui media social, hal tersebut terlihat dari strategi yang digunakan dalam membentuk, menyebarkan, dan memonitor informasi 
berdasarkan karakteristik media sosial dan informasi sesuai dengan karakteristik pemilik akun media sosial (Greg, 2005).

Penerapan manajemen pengetahuan harus didukung dengan kompetensi SDM yang memadai. Kompetensi manusia dalam organisasi untuk memastikan peran dan tanggung jawab setiap individu dalam organisasi ketika mengelola pengetahuan dan menjalankan proses manajemen pengetahuan (mempelajari, meningkatkan, atau mengalirkan pengetahuan). Dalam manajemen pengetahuan melalui media sosial, pengelola akun menjadi menjadi perhatian masyarakat, Mereka merespon aktivitas di media sosial harus memahami dan sudah terbiasa dengan media sosial dan bekerja sesuai perannya dalam tim (Dessler, 2004; Yusup, 2012).

Salah satu kendala dalam menjalankan pekerjaannya adalah topik/isu yang bergulir di media sosial selalu baru tetapi informasi yang diterima oleh masyarakat tidak sesuai. Untuk itu, staf ahli selalu memperbaharui pengetahuannya misalnya dengan mengikuti kegiatan seminar ataupun workshop yang diselenggarakan oleh LNM atau melalui milist komunitas jurnalistik.

\subsubsection{Eksternalisasi}

Eksternalisasi merupakan tahapan transfer pengetahuan dari pikiran pemiliknya ke tempat penyimpanan eksternal dengan cara seefisien mungkin atau disebut juga berbagi pengetahuan (Fauziah, 2015). Pada tahap ini, ada upaya mentransfer pengetahuan sesuai dengan momentum serta minat dan emosi masyarakat. Hal tersebut dikatakan Ali dan Jeni:

"Pemanfaatan momentum merupakan hal yang utama dalam pembentukan opini melalui medsos. Momentum tersebut yang nantinya akan menyesuaikan dengan minat dan emosi masyarakat agar kemudian menjadi tertarik untuk terus mengikuti pemberitaan mengenai si pemilik akun, 20 Desember 2016"; "Kedua, pencipta opini harus menyentuh emosi pembaca / publik untuk menarik simpati, 23 Desember 2016".

Penyesuaian minat atau emosi masyarakat ketika transfer pengetahuan merupakan aspek orang. Informasi yang disampaikan berdasarkan momentum, minat, dan emosi masyarakat. Hal ini lebih disukai dan lebih menarik perhatian masyarakat.

Selain itu, ada aspek melaporkan kinerja Anggota LNM, dengan cara memasukkan aktivitas foto kegiatan anggota ke dalam media sosial. Dalam proses ini, staf ahli harus turun lapangan agar dapat melihat fakta yang terjadi. Hal tersebut dikatakan Jeni:

"Kami pengelola medsos juga diminta untuk selalu mengikuti kegiatan yang kaitannya dengan jabatan politisnya, setelah itu apa yang kami lihat dan si subjek kerjakan kamu masukkan dalam medsos, 23 Desember 2016".

Dalam tahap eksternalisasi manajemen pengetahuan, aspek teknologi pada tahap ini adalah staf ahli memanfaatkan alat perekam yang ada maupun cetak layar dari narasumber yang kita butuhkan informasinya, hal tersebut sesuai dengan perkataan Jono.

"Nah kalau dari narsum biasanya kita track ataupun screen shoot dari medsos doi mbak. Kadang kalau memang lagi ada acara sesuai dengan apa yang kita lagi monitor kita biasanya langsung rekam aje mba itu yang ngomong. Kadang kalau yang kita butuh frame kondisional ya kita rekam adegan mba dan menyuarakan apa yang kita lagi garap. Cuma itu aja kok mba, 28 Desember $2016 "$.

Aspek teknologi pada tahapan ini merupakan aspek yang mendukung pembentukan informasi yang valid bagi masyarakat. Kemampuan staf ahli dalam menggunakan teknologi 
untuk koordinasi tim serta memperlancar tugas dalam mengumpulkan, mengelola, serta menyebarkan informasi pada masyarakat tidak diragukan karena mereka sudah terbiasa dalam menggunakan teknologi dalam kehidupan pribadi sehari-hari. Pada tahapan ini, terkadang tim media sosial berjalan tidak sesuai karena adanya kepentingan individu dalam tim salah satu contoh Joko yang lebih dahulu bekerja sebagai staf ahli ini terkadang menjadi pribadi yang lebih senior dibanding dengan staf ahli lainnya, sehingga dengan mudahnya Joko memberikan perintah dalam proses tahap ini kepada Jeni yang lebih junior.

\subsubsection{Internalisasi}

Konsep internalisasi pada proses manajemen pengetahuan merupakan pengambilan pengetahuan dari tempat penyimpanan eksternal, dan penyaringan pengetahuan tersebut untuk pencari yang relevan. Pengetahuan harus disajikan ke pengguna dalam bentuk yang lebih cocok dengan pemahamannya. Fungsi ini mencakup interpretasi format ulang penyajian pengetahuan. Intepretasi dalam tahap ini adalah membentuk atau mengambil informasi sesuai dengan pemikiran subjek yakni anggota Lembaga Negara Mahardhika yang dilakukan oleh staf ahli yang memiliki kewenangan dalam memegang akun media sosial dari anggota Lembaga Negara Mahardhika tersebut. Tahap internalisasi ini yang paling efektif sesuai dengan wawancara ialah berkomunikasi secara langsung dengan pemilik akun media sosial tersebut. Adakalanya komunikasi antara staf ahli dengan pemilik akun melalui orang ketiga, yakni perantara seperti salah satu dari keluarga pemilik akun. Dari salah satu perintah keluarga pemilik akun yakni seorang anggota Lembaga Negara Mahardhika tersebut kemudian staf ahli mengerjakan dan menyebarkan informasi yang diinginkan di media sosial. Hal tersebut sesuai dengan perkataan Siska yang merupakan anak kandung dari Pemilik akun.

"Makanya saya suka kan WA kak Jono, ayo kak, share dong ke akun Papa..., 12 Januari 2017".

Paparan di atas adalah WA yang kerap ditujukan oleh tim sosial media untuk menyebarkan informasi ke akun media sosial milik ayahnya. Proses membangun komunikasi verbal yang terus dilakukan oleh staf ahli seperti yang disampaikan di atas tidak lain merupakan aspek proses dimana staf ahli selalu berupaya untuk mencari tahu keputusan yang akan diambil oleh Anggota Lembaga Negara Mahardhika ini yang memiliki akun media sosial tersebut.

Aspek selanjutnya dalam tahap internalisasi manajemen pengetahuan yakni aspek orang, di mana staf ahli ini mengorek informasi tentang pikiran Anggota Lembaga Negara Mahardhikaini dengan berbagai cara (Greg, 2005). Hal tersebut sangat penting karena terkadang informasi yang diperoleh terkadang terbatas dan tidak sesuai, sehingga staf ahli harus memiliki cara untuk mencari tahu informasi tambahan untuk diramu menjadi informasi yang layak untuk konsumsi publik.

Meskipun staf ahli memiliki informasi mereka juga memiliki etika dalam manajemen pengetahuan yang dimiliki untuk dipublikasikan untuk umum. Menurut Waryanto (2006), bahwa seseorang perlu menjaga etika di media sosial karena disebabkan oleh beberapa alasan, diantaranya: (1) pengguna media sosial berasal dari berbagai negara yang mungkin memiliki budaya, bahasa dan adat istiadat yang berbeda-beda; (2) pengguna internet merupakan orang-orang yang hidup dalam dunia anonim, yang tidak mengharuskan pernyataan identitas asli dalam berinteraksi; dan (3) harus diperhatikan bahwa pengguna internet akan selalu bertambah setiap saat dan memungkinkan masuknya "penghuni" baru di dunia maya tersebut. Sehingga informan yang dalam penelitian ini 
merupakan staf yang menangani media sosial sudah sewajarnya untuk memiliki etika dalam berkomunikasi dengan pengguna di media sosial.

Dalam melakukan tahapan ini, masih ada sedikit kesalahan dalam penulisan. Akan tetapi dengan cepat tim staf ahli segera mengedit kesalahan tersebut. Dalam penerapan yang terjadi di lapangan, kekompakan tim juga mempengaruhi konten informasi yang sudah didapatkan oleh staf ahli junior yakni Jeni dan Ali sebelum disebar ke masyarakat harus diperiksa terlebih dahulu. Namun kenyataanya dalam praktiknya bahwa informasi tersebut tidak diperbaiki dan tidak mendapat respon masukan apa pun.

\subsubsection{Kognitif}

Setelah melalui tiga tahapan sebelumnya, tahap selanjutnya adalah kognitif yang merupakan respon dari informasi yang telah disebarkan oleh staf ahli kepada masyarakat. Respon yang ada dalam media sosial terhadap informasi yang bersifat kelembagaan yang beredar dalam beraneka ragam, lebih bersifat pro dan kontra. Masyarakat menanggapi isu yang disebar dengan berbagai cara, di antaranya dengan membalas komentar di kolom media sosial kelembagaan, atau pun mereka tidak segan untuk mengirim pesan secara pribadi.

Sikap yang diambil oleh semua informan menanggapi respon dari masyarakat adalah melakukan perintah dari atasan, karena informan menyadari tentang etika dalam komunikasi yang harus dijaga terkait dengan citra pemilik akun yakni Anggota Lembaga Negara Mahardhika. Penjelasan di atas dapat dikaitkan dengan aspek manusia dalam tahapan ini yakni adanya perintah atasan yang merupakan motivasi dalam bersikap menanggapi informasi serta partisipasi tim, adanya persamaan pemilikiran, dan kerjasama seluruh tim. Sementara itu, ada kalanya ketika informan menanggapi informasi yang beredar di masyarakat, muncul naluri untuk mengklarifikasi isu informasi yang sebenarnya.

Tahap kognitif adalah tahap di mana informan menganalisis informasi yang ada pada media sosial, berdasarkan bentuk teknologi yang menjadi pendukung penting agar informasi yang beredar sesuai dengan yang diinginkan serta dapat membuat keputusan untuk mengambil langkah selanjutnya. Teknologi merupakan salah satu aspek pokok yang terdapat pada manajemen pengetahuan, dikenal sebagai media yang mempermudah penyebaran pengetahuan eksplisit. Internet sendiri menyediakan fitur agar kebutuhan untuk mengakses manajemen pengetahuan dan melakukan kolaborasi, komunikasi serta berbagi pengetahuan yang dapat dilakukan dengan lebih mudah, cepat, dan dalam waktu yang bersamaan (Sigala \& Chalkiti, 2015; Rusilowati, 2014). Informasi yang disebarkan melalui akun media sosial berupa twitter, facebook, dan instagram. Facebook merupakan media sosial yang paling efektif untuk membentuk opini masyarakat dibanding dengan media lainnya karena media sosial tersebut banyak yang memberikan respon.

\subsubsection{Evaluasi}

Dalam konsep manajemen pengetahuan melalui media sosial, evaluasi terhadap proses berbagi dan manajemen pengetahuan merupakan kegiatan untuk mengevaluasi, menilai, memetakan informasi, cara pengambilan keputusan setelah empat proses tahapan yang dilakukan. Pada proses evaluasi di Lembaga Negara Mahardhika, kegiatan ini dilakukan secara kontinu, misalnya harian, mingguan, atau bulanan, sesuai dengan informasi yang sedang hits di perpolitikan bangsa. 
Usaha secara bersama-sama yang dilakukan oleh tim dalam memonitor informasi merupakan bentuk pengukuran hasil informasi yang disebarkan oleh staf ahli, mereka melakukannya secara berkala sesuai dengan frekuensi yang dibutuhkan. Kegiatan memonitor secara bersama-sama secara tidak langsung merupakan pemantauan aspek manusia. Media untuk memonitor adalah aspek teknologi untuk mendukung aktivitas berbagi dalam manajemen pengetahuan yang dilakukan. Hal tersebut merupakan sarana yang penting untuk terwujudnya informasi yang sesuai dengan kategorinya serta menciptakan solusi jika terdapat masalah.

Sementara itu, aspek proses yang ada dalam tahapan sesuai dengan yang disampaikan oleh Jono bahwa tujuan memonitor adalah untuk menilai program yang sesuai untuk dibangun di masa yang akan datang. Evaluasi merupakan tahapan yang berkaitan erat dengan kegiatan monitoring. Dalam merencanakan suatu kegiatan hendaknya evaluasi merupakan bagian yang tidak terpisahkan, sehingga dapat dikatakan sebagai kegiatan yang lengkap. Evaluasi diarahkan untuk mengendalikan dan mengontrol ketercapaian tujuan. Evaluasi berhubungan dengan hasil informasi tentang nilai serta memberikan gambaran tentang manfaat suatu kebijakan. Istilah evaluasi ini berdekatan dengan penafsiran, pemberian angka dan penilaian. Evaluasi dapat menjawab pertanyaan "apa pebedaan yang dibuat" (Dunn, 2000).

\section{KESIMPULAN}

Dapat ditarik kesimpulan bahwa proses transfer pengetahuan melalui media sosial oleh staf ahli anggota Lembaga Negara Mahardhika cenderung dilakukan sebagai proses pengumpulan informasi dalam upaya pencocokan antara agenda komunikasi dengan tren subjek yang ada, sehingga agenda komunikasi dapat berjalan berdampingan dengan tren yang bersangkutan. Proses tersebut merupakan proses intermediasi, yang didasari oleh pemahaman tim staf ahli bahwa media sosial yang berkaitan dengan korporasi atau organisasi, dimaknai sebagai media yang bertujuan untuk menyediakan informasi kepada publik sesuai dengan momen yang ada. Sementara itu, tujuan penggunaan media sosial oleh staf ahli lebih ditujukan untuk menjangkau masyarakat lebih luas. Media sosial yang paling efektif dalam penyebaran informasi ke masyarakat adalah facebook, kemudian twitter dan instagram. Hasil analisis menunjukkan bahwa media sosial facebook merupakan media yang paling banyak direspon oleh masyarakat. 


\section{DAFTAR PUSTAKA}

Bhatt, Dilip. 2000. "Excellence Model and Manajemen Pengetahuan Implications. Di http://www.eknowledgemanagementcenter.com/articles/1010/1010.htm (Akses 25 September 2016).

Chua, A. and S. Banerjee. 2013. Customer Knowledge Management via Media sosial: The Case of Starbucks. Journal of Knowledge Management, 17, No. 2: 237-249.

Connaway, Lynn Silipigni and Ronald R. Powell. 2010. Basic Research Methods for Librarians. California: Libraries Unlimited.

Dalkir, Kimiz. 2011. Manajemen Pengetahuan: in Theory and Practice. London: The MIT Press.

Dessler, Gary. 2004. Manajemen Sumber Daya Manusia. Jakarta: PT. Indeks Gramedia.

Dhiman, Anil Kumar and Hemant Sharma. 2009. Knowledge Management for Librarians. New Delhi: Ess Ess Publications.

Dunn, William N. 2003. Analisis Kebijakan Publik. Yogyakarta: Gadjah Mada University Press.

Fauziah, Kiki. 2015. Berbagi Pengetahuan untuk Mengembangkan Kompetensi Staf Perpustakaan BI. Tesis. Depok: Universitas Indonesia.

Frappaolo. C and Tom. 1997. Knowledge Management. From Terra Incognitas to Terra Firma. Di http://www.delphigroup.com (Akses 25 September 2016).

Greg, Timbrell. 2005. A Structurationist Review of Knowledge Management Theories. Brisbane: Queensland University of Technology. Di http://eprint.qut.edu.au/10104/1/10104_2.pdf (Akses 20 Agustus 2016).

Hislop, Donald. 2009. Knowledge Management. United Kindom: Oxford Press.

Multiningsih, Bekti dan Kelly Johnson. 2014. Usulan Kerangka Kebijakan Penggunaan Media Sosial untuk Perpustakaan Perguruan Tinggi. BACA: Jurnal Dokumentasi dan Informasi, Vol. 35, No. 2: 73-84.

Nirmala, M. and M. Vemuri. 2009. Leveraging Informal Networks in Knowledge Management. Journal of Knowledge Management, Vol. 13, No. 3: 146-156. http://doi.org/10.1108/13673270910962932.

Nonaka, I., and R. Toyama. 2003. The Knowledge-Creating Theory Revisited: Knowledge Creation as a Synthesizing Process. Manajemen Pengetahuan. Research \& Practice, Vol. 1, No. 1: 2-10.

Rusilowati, Umi. 2014. Analisis Manajemen Pengetahuan (Knowledge Management) Berbasis Teknologi Informasi (TI) dalam Konteks Pembelajaran Organisasi (Learning Organization) (Studi Kasus Pada Lembaga Penelitian dan Pengembangan Pemerintah). Disertasi. Bandung: Universitas Pasundan. 
Sigala, M., and K. Chalkiti. 2015. Knowledge Management, Media Sosial and Employee Creativity. International Journal of Hospitality Management, No. 45: 44-48.

Sudarsono, Blasius dan Prafita Imadianti. 2012. Pustakawan Memandang Knowledge Management. BACA: Jurnal Dokumentasi dan Informasi. Vol. 33, No. 2 (Desember): 1-11.

Yates, Dave, and Scott Paquette. 2011. Emergency Knowledge Management and Media Sosial Technologies: A Case Study of The 2010 Haitian Earthquake. International Journal of Information Management, Vol. 31, No. 1 (February): 6-13.

Yusup, Pawit M. 2012. Perspektif Manajemen Pengetahuan Informasi, Komunikasi, Pendidikan, dan Perpustakaan. Jakarta: PT. Raja Grafindo Persada. 